\title{
First Black Military Pilot of the World: Ottoman Lieutenant Ahmet Ali Bey 1883 - 1969
}

\author{
Halim Gençoğlu \\ Department of African Studies, University of Cape Town, Cape Town, South Africa \\ Email address: \\ gnchal001@myuct.ac.za

\section{To cite this article:} \\ Halim Gençoğlu. First Black Military Pilot of the World: Ottoman Lieutenant Ahmet Ali Bey 1883 - 1969. International Journal of \\ European Studies. Vol. 5, No. 1, 2021, pp. 1-6. doi: 10.11648/j.ijes.20210501.11
}

Received: February 8, 2021; Accepted: February 20, 2021; Published: March 26, 2021

\begin{abstract}
A forgotten prominent figure, Ahmet Ali Çelikten was the first black military pilot in world history. Of Nigerian origin, Ahmet Ali grew up in the Ottoman society and had the opportunity like any Ottoman Turkish citizen to study in the Ottoman naval force in 1903. He fought in the Italian-Turkish war with his South African coreligionists in Libya in 1911 and later against the allies in WW1 as the first black military pilot in the World. The Ottoman Empire was the last Islamic and multi-cultural empire in world history. Skin colour did not affect individuals' social standing or opportunities in the Ottoman society. The Ottoman Empire managed to rule several nations, even those with religious minorities and provide them equal rights. This article aims to highlight the events and experiences in the life of Pilot Ahmet Ali in the Ottoman territory. To achive this, Ottoman archival sources and otantique Turkish journals were used during the research. In addition, comparative method was used throughout the study by looking at the social life in the Ottoman Empire and in the Western world in the light of archival documents. In conclusion, this understanding and living conditions enabled Ahmet Ali to be the first black pilot in the world history. At a difficult time in the history of the Ottoman Empire, during the genesis of modern Turkey, Ahmet Ali Bey had sincerely contributed to establishment of a Turkish air force in the Republic of Turkey.
\end{abstract}

Keywords: Ahmet Ali Çelikten, First Black Pilot, Aviation History, Ottoman Empire, Turkey

\section{Introduction}

This article aims to reveal the life of an interesting historical figure regarding the first black pilot in the world, Ahmet Ali Bey, and his activities in the last century of the Ottoman Empire. Ahmet Ali was an African man, of Nigerian origin, who studied and lived in the Ottoman city of Izmir his entire life.

In Ottoman law, there was no classification based on race or skin colour. The Constitution identified people in terms of their religious identity. They could either be Muslim or Zimmi. Zimmi is a historical term referring to non-Muslims living in an Islamic state with legal protection. The Zimmi people included non-Muslims like the Armenians, Jews or Greeks paid different tax from Muslims citizens and were exempted from military service, which was compulsory for all Muslim citizens. These non-Muslim groups might be considered a minority in the Ottoman Empire. Therefore, Afro-Turks were never regarded as a minority because they belonged to the Muslim majority, which was clearly stated in the Ottoman Law but also in the Turkish constitution. Basically, according to Ottoman law, an Afro-Turk, Kurd or Oguz Turk was treated equally in the Ottoman State. This is how the Afro-Turk, Ahmet Ali Celikten, found an opportunity to become the first black pilot in the World. Like him, many other commanders of African origin worked in the Ottoman army as lieutenants or high rank soldiers.

As a black citizen, Ahmet Ali was never discriminated against in the Ottoman army because of the multi-cultural social and religious understanding existing in the Ottoman society. Ahmet Ali Bey lived at a time when it was very difficult for non-white nations to obtain education and improve their knowledge in most Western States. Racism and discrimination did not allow them to study as "civilised people" in the West. For instance, the case of another black pilot, Eugene Jacgues Bullard, who struggled to study in his own country France, during that time, shows how the social 
sphere was not only segregationist but also intolerant towards others in the western world.

Bullard struggled to gain acceptance in France and as well as America because of his skin colour and worked as a perfume salesman, a security guard, and an interpreter. On the other hand, as a Turkish citizen, Ahmet Ali Bey was lucky enough to study in Turkey [1].
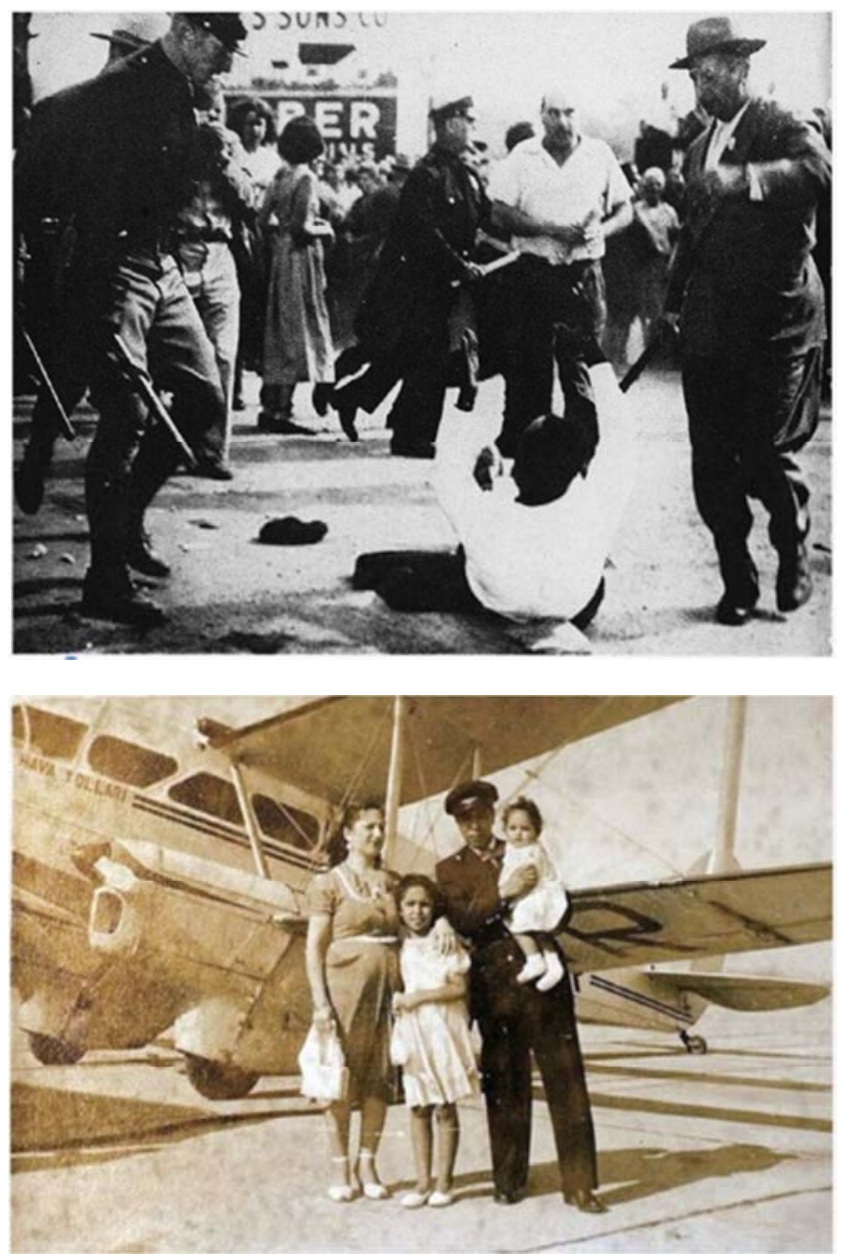

Figure 1. The world's second black pilot, on the top image, Lieutenant Eugene Bullard was beaten by racist New York police and died while working in a perfumery store in the 1950s. At the bottom, the world's first black pilot, Colonel Ahmet Ali Çelikten, retired from the Turkish Air Force with a medal of honor.

Ahmet Ali Bey was also called Arab Ali in public. This is a common word usually used for African Muslims to signal their regional origins. People like pilot Ahmet Ali Bey, famous musicians and Turkish movie stars of African origin have been given positive recognition in the Turkish public sphere from to past to the present [2]. In order to identify their national origins, most of them preferred to use particular surnames to indicate their Afro-Ottoman identity. Unlike these notable actors and musicians, pilot Ahmet Ali Bey used the Celikten surname which means "steely" and solid [3]. In this article, I will look at the life and legacy of pilot Ahmet Celikten from the decline of the Ottoman Empire to the emergence of modern Turkey [4].

\section{Pilot Ahmet Ali Bey's Origins}

Ottoman pilot and senior lieutenant Ahmet Ali Bey was born in Izmir in 1883 of African parents. Ahmet Ali's father was also called Ali Bey and his mother was Zenciye Emine, originally from Nigeria. Zenciye Emine's mother was brought from the Borno province in Nigeria and lived in Istanbul from around 1830 [5]. We do not know much about Zenciye Emine's mother but according to family reports, she was bought by an Ottoman notable, the general secretary of the governor of Istanbul, the Ihtisap Agasi Katibi in Ottoman Turkish. Zenciye Emine's mother worked in the palace during her life and had three children. Of the three children, only Zenciye Emine is known to us, and it is she who was the mother of our hero, Ahmet Ali Bey. Zenciye Emine married Ali Bey who also originally Nigerian but lived in Asia Minor as an Ottoman citizen. Pilot Ahmet Ali Bey's father Ali Bey was from Izmir, where most Ottoman citizens of African origin preferred to live since the Ottoman era until the present [6].

Ali Bey and Zenciye Emine had three children, Ahmet Ali, Zenciye Saniye and Ali, which shows that the family was very much attached the name Ali perhaps because of its importance in the family history. Ahmet Ali was the eldest child of the family. When Ahmet Ali was still a child, he lost his father and assumed the responsibility as the eldest son of the family. He helped his mother with family affairs and, at the same time, began to study at the school of Blooming Mill (Heddehane Mektebi) in 1904 [7]. In that school, students used to study mechanical sciences, languages, and military systems. Ahmet Ali was a successful student and undoubtedly, his studies at this school improved his knowledge and mind-set [8]. He graduated from there as a lieutenant, which was the first official Ottoman degree in the Ottoman military system (Mulazimi Evvel) [9].

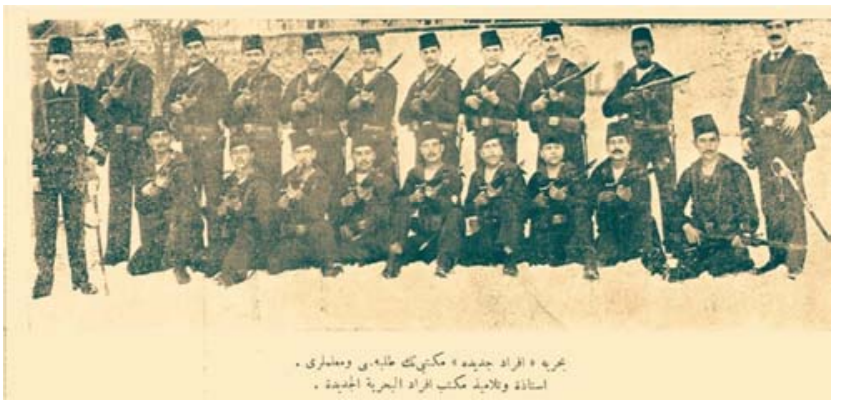

Figure 2. Pilot Ahmet Ali Bey in naval training school with his fellow friends in 1904.

\section{Ahmet Ali Bey's Introduction to Aviation}

Ahmet Ali's youth coincided with the invention of the flying machine and the production of what became accepted as the first aircraft in world history. By 1903, the Wright brothers had attempted their first flying experiment [10]. In 
1909, the United States acquired their first military aircraft. In fact, all states had understood the significance of an air force in the military system. Italy was the first to use an air force in the Turkish-Italian War in Libya and occupied Tripolitania [11]. On October 23, 1911, an Italian pilot, Captain C. Piazza, flew over Turkish lines on the world's first aerial reconnaissance mission, and on November 1, the first ever aerial bomb was dropped by S. G. Gavotti on Turkish troops in Libya from an early model of the Etrich Taubearcraft. In retaliation of this event, for first time in history, the Ottoman Army dropped a military aircraft in world history. This indicates that despite the declining state of the Ottoman Empire, it was well-aware of all these technological developments [12]. Ahmet Ali also attended the war between the Ottoman Empire and Italia in Tripolitania. In this war, Ahmet Ali met another Afro-Ottoman commander and spy, Zenci Musa who was originally from Sudan, and known as Black Moses in the Western world. He was living in Cairo his grandfather was an admirer of the Ottoman State, he sent himto Istanbul to study Islam in the capital of the Ottoman Empire. Zenci Musa learnt Turkish and voluntarily left for Tripoli to fight against the Italians, in a war led by the Turkish officers and the entire Islamic world. Likewise, some Indian Muslims from South Africa joined to Ottoman army to fight against the Italians for the Unity of Islam [13].

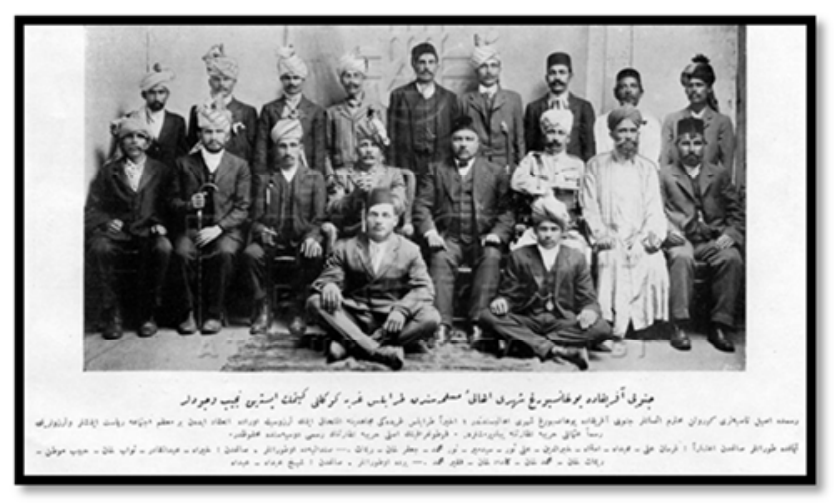

Figure 3. A photo of South African Muslims was taken in South Africa in 1911. This photo was sent to Ottoman State by the South African Muslims who were keen to fight against Italia in Libya during the Turco-Italian War 1911-1912. Voluntary muslim soldiers from Johanesburg, At the back from right to left; Tirman Ali, Amidah, Emtah, Hayreddin, Ali Sur, Seyyid Mir, Nur Muhammed, Cafer Han, Rimat. Sitting on the chairs, Hayrah, Abdülkadir, Nüvvab Han, Habib Mevtın, Rimat Han, Muhammed Han, Güldad Han, Nakir Muhammed. Sitting in front Şeyh Ibdah, Abdullah.

On 13 October 1910, the chief of the Ottoman army, Mahmud Sevket Pasha, sent a letter to the director-general of the fortified areas of the Ottoman State, instructing the purchase of a few aircrafts for the Ottoman State. This instruction from Mahmud Sevket Pasha would be the first step towards the emergence of the Ottoman Air Force in history. Thereupon followed another order from Mahmud Sevket Pasha instructing that a few talented students be sent to England and France in order to learn and practise their aviation skills. During this period, Ahmet Ali was trained and became the one of the brightest officers in the army.

Ottoman archival sources provide remarkable information about Ahme Ali's education at the military aviation school [14]. On 11 November 1916, the chief pilot of the Ottoman aviation school sent a letter to the general minister of defence of the Ottoman state stating, "due to successful results and examinations of the pilot candidate, Mr Ahmet Ali received his pilot's degree which must be prepared on his behalf as soon as possible." Thus, Ahmet Ali officially became lieutenant senior on 14 February 1917. Thereafter, he was sent to Germany for further education, returning to Turkey in 1918 [15]. He was one of the chosen students sent to the aviation schools of Ecole Bleriot in France and that of Bristol in England. The main criterion for their selection was their educational background and the process was carefully conducted by the commanders in the Ministry of War of the Ottoman State. Therefore, students like Ahmet Ali, chosen by the air force to be sent overseas, were selected because they had mechanical knowledge in engineering fields, making it easier for them to understand the structure of 'flying machines', basically the Aircraft [16].

In 1912, the Ottoman State established an aviation school at Yesilkoy airport in Istanbul. Thereafter, an Ottoman sea aviation school was established in the same region on 25 June 1914. Ahmet Ali Bey was one of the first officers in this aviation school, which specialised in naval air combat, with the assistance of Air Force. The Director of Turkish aviation school was a French commander, De Goys. Only three days after its establishment, on 28 June 1914, the First World War broke out. Immediate participation in the war was a decision which had to be taken by statesmen and generals during the July Crisis of 1914. This crisis was caused by the assassination of Archduke Franz Ferdinand, an ethnic Serb and Yugoslavic nationalist from the Young Bosnia Group, which was supported by the Black Hand, a nationalist organisation in Serbia. Because of the war situation, Mr De Goys returned to France. Due to the German-Ottoman States alliance, a new German officer and school director, Mr Serno began to train Ahmet Ali in aviation. A local Nigerian newspaper highlights the war situation and the German attitude during the First World War. According to the Nigerian Pioneer news, 'The German hoisted a green Ottoman flag at Bailly, hoping doubtless to impress the French Mohammedan and African troops who promptly replied by tinning on and capturing the flag' [17]. This news indicates that German statesmen wished to use the influence of the Ottoman Caliphate on the African Muslims as far as Nigeria.

The year 1918 was the most critical year because it was during this time that the results of First World War changed the destinies of many nations. Russia's main goals included strengthening its role as the protector of Eastern Christians in the Balkans (such as the Serbians). Although Russia enjoyed a booming economy, growing population, and large armed forces, its strategic position was threatened by an expanding Turkish military, trained by German experts using the latest 
technology. The start of the war renewed attention to Russia's other old goals: expelling the Turks from Constantinople; extending Russian dominion into Eastern Anatolia and Persian Azerbaijan; and annexing Galicia. These conquests would ensure Russian dominance in the Black Sea and its access to the Mediterranean regions. The last great Islamic Empire was on the verge of decline [18].

Under these circumstances, Ahmet Ali volunteered to go to the Konya Air Force Base in Anatolia in order to support his countrymen against the occupation by Western powers and Russia. By 1918, the Ottoman Empire signed the armistice of Mudras and withdrew from the war; however, these peace conditions were not acceptable to some intelligent Ottoman Statesmen like Mustafa Kemal Ataturk. Mustafa Kemal Ataturk started a war of independence in Asia Minor against the occupying forces of the Western states and called all patriots to join this war at the centre of Anatolia. Ahmet Ali heeded Ataturk's message and worked for the independence of the Turkish State. Historian David Nicolle notes that:

Most Ottoman aircrew were recruited from the Turkish heartland... others came from the Arab provinces of the Ottoman Empire as far south as Yemen, or even from neutral Iran. Captain Ahmet was of Arab-African origin and may have been the first 'black' Air Force pilot in aviation history, having received his 'wings' in 1914-15 [19].

In 1922, British army naval forces were still a threat to the Ottoman State in the capital, Istanbul. British occupation in Istanbul continued until Ataturk's victory in the War of Independence, a victory against all the colonialist western states such as France, Italy and Great Britain and Belgiam For this reason, in 1922, Ahmet Ali left for the city of Amasra on board his aircraft in order to support the Turkish national army, led by Mustafa Kemal Ataturk [20]. During this war, Ahmet Ali fought for his country as a pilot and contributed to the independence of the Turkish State. In one of his family photos, Ahmet Ali is seen flying with a special manoeuvre aircraft Breguet 19s, a French military airplane. Like Ahmet Ali, other Turkish pilots were very fond of the Breguet especially acquired during the years of the War of Independence in the 1920s. As a result of an order of 20 Brequet 19.a2s model aircrafts was placed in 1924. The planes were handed over to the Turkish authorities and were deployed at the $2^{\text {nd }}$ and $9^{\text {th }}$ airplane squad which was situated in Eskisehir [21].

In 1924, the new Turkish Republic established an aviation school in Izmir and Ahmet Ali was appointed as a commander and teacher in this school. He then settled in Izmir and was appointed as counsellor in the Turkish air force. He was awarded the naval force medal for his services as a pilot. This is the last archival document in Ottoman archive about his official activities in Turkish army. He served in the Turkish army up until 1949 and then retired. Ahmet Ali Bey received recognition as a hero pilot in Turkish army [22]. When he died in 1969, a special funeral ceremony was organized for him. Pilot Ahmet Ali Bey played a prominent role in the establishment of the Turkish air force in Turkey [23].

\section{His Family}

Ahmet Ali married Mrs. Hatice and had 4 children from her, Muhammer, Yilmaz, Mujgan and Neriman. All the children received a good education, most of them following in their father's footsteps and becoming pilots. Moreover, because of the influence Ahmet Ali had, his other family members also preferred to become professional pilots. Ahmet Ali used Celikten as the surname for his family. Until today, the Celikten family continues to live in Izmir [24].

\section{Conclusion}

Ahmet Ali Bey was the first black aviator in World history. He was living at a time when it was very difficult for people of colour to obtain education and improve their knowledge in most Western States. Racism and discrimination did not allow them to study as "civilised people". The story of another black pilot, Eugene Jacgues Bullard, who at the time struggled seriously in his own country France to survive, shows how the social structure and social sphere were not only segregationist but also intolerant towards others in the western world. Bullard was ill-treated in France and as well as in America because of his skin colour and worked as a perfume salesman, a security guard, and an interpreter. His final job was as an elevator operator [26].

On the other hand, Ahmet Ali Bey was lucky enough to stay on the Ottoman soil. He had the opportunity to study and became a notable officer in Ottoman Army. As an African man, he was never separated from his co-religionists in Turkey but became a full citizen under the Ottoman rule. Like Ahmet Ali Bey, the first Muslim female pilot, Belkis Sevket, was also an Ottoman citizen. She lived in the last decades of the Turkish-Islamic state and became the first woman pilot in the world, another example of the social tolerance and progressive understanding on the Ottoman soil. These factors indicate that it is not only the talent of pilots like Ahmet Ali or Belkis Sevket, but rather the opportunities which were created for all human beings to acquire education. This is the more important driving factor that ensured that they achieved their aspirations like other heroes in world history [27].

At a difficult time in the history of the Ottoman Empire, during the genesis of modern Turkey, Ahmet Ali Bey had sincerely contributed to establishment of a Turkish air force in the Republic of Turkey. His activities and influence cannot be forgotten in terms of the historical developments of the Turkish military systems from the past to the present. 


\section{Appendix}

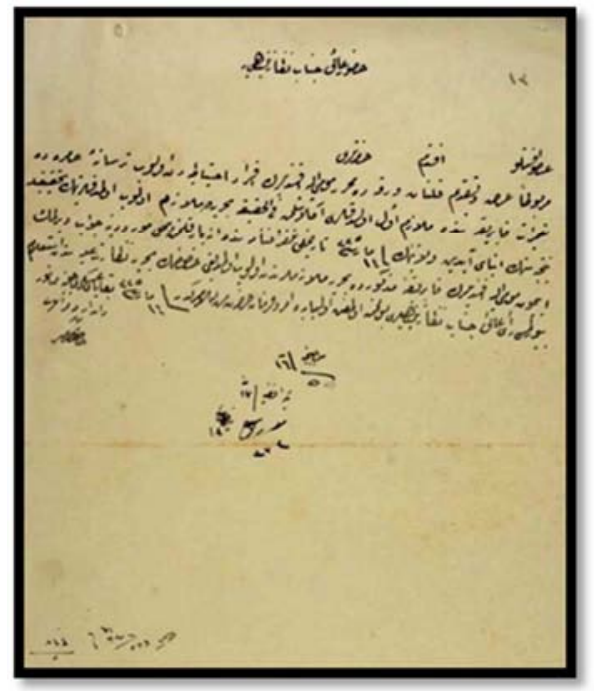

Figure 4. An Ottoman Archive document regarding Ahmet Ali's first attempt to the military school in Izmir, 1904.

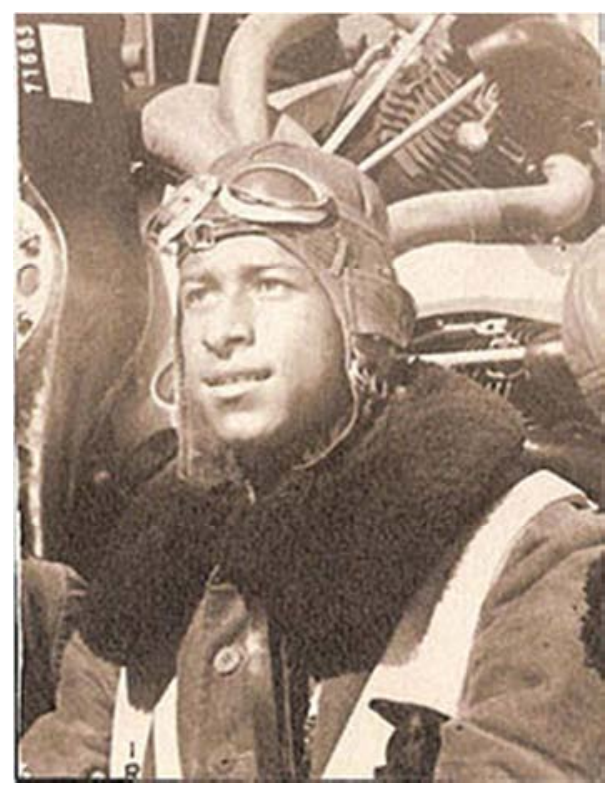

Figure 5. Ahmet Ali at the flight school in Istanbul.

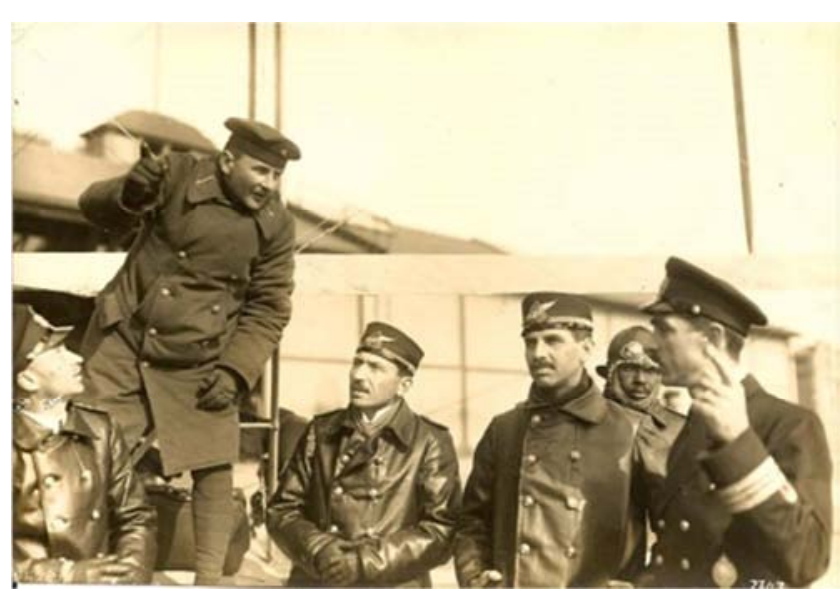

Figure 6. Ahmet Ali at the training school in Istanbul.



Figure 7. Ahmet Ali with his colleagues in Kayseri, 1940s.

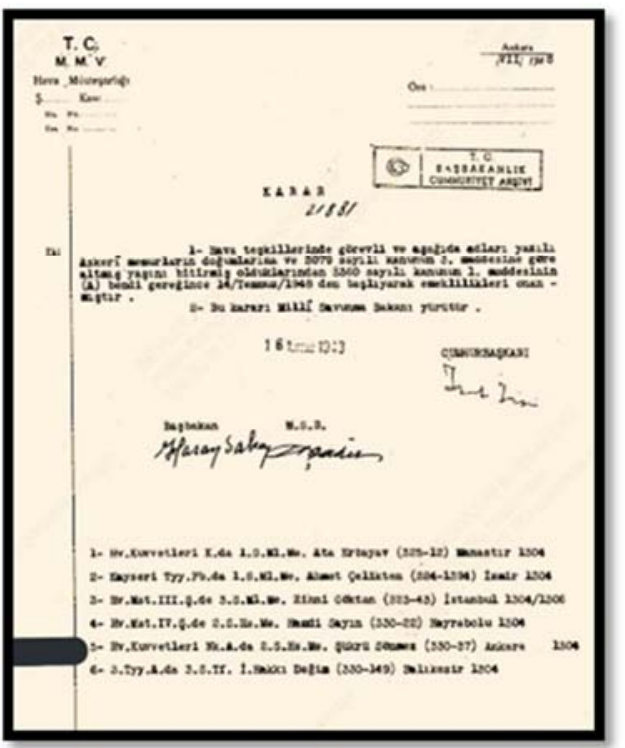

Figure 8. Pilot Ahmet Ali Bey's pension certificate, 1948

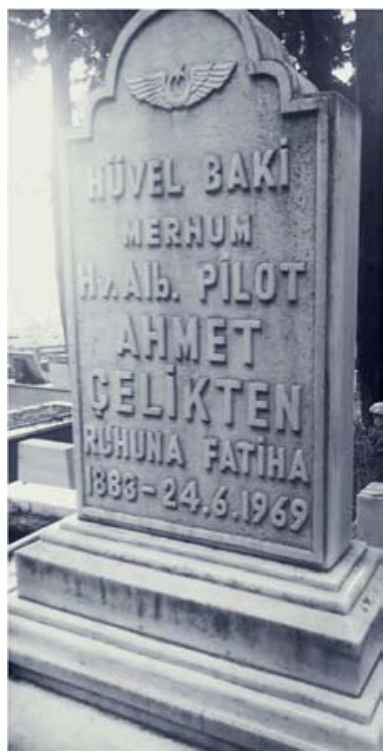

Figure 9. Pilot Ahmet Ali Bey's gravestone, Turkey. 


\section{References}

[1] Gencoglu, Halim, 2019, The First Black Pilot of the World: Ahmet Ali Bey of Nigerian Origin (Dünyanın ilk siyahi savaş pilotu: Nijeryalı Ahmet Ali Bey (Çelikten) 1883 - 1969, Independent Turkish, Retrieved from https://www.indyturk.com/node/27686/t\%C3\%BCrkiyedensesler/d\%C3\%BCnyan $\%$ C4\%B1n-ilk-siyahi-sava $\%$ C5\% $\%$ Fpilotu-nijeryal $\% \mathrm{C} 4 \% \mathrm{~B} 1$-ahmet-ali-bey-\%C3\%A7elikten-1883 accessed 03. January. 2021.

[2] Turkish Movie star Yasemin Esmergül and Singer Esmeray are the most well-known characters in Turkey.https://www.thenationalnews.com/artsculture/esmeray-the-untold-story-of-an-afro-turk-music-star1.166767, accessed. 02. 04. 2021.

[3] Posta, "First Black Pilot of the World" "Dünya'nın ilk siyahi pilotu: Arap Ahmet -4 Pilotlarla Dolu Bir Aile"20 March 2011, p. 2. Retrieved from, https://www.posta.com.tr/dunyanin-ilksiyahi-pilotu-arap-ahmet-65707, February 19, 2021.

[4] Gencoglu, Halim 2020, Africa-Turkey: In the Turkish Archival Sources, Ankara, SR Press.

[5] Donanma MecmuasI, no; 80 - 8, February 1911.

[6] Kurter, Ajun. 2009. Türk Hava Kuvvetleri Tarihi: cilt III (1917 y1l1). Istanbul: Türk Hava Kuvvetleri Komutanlığı.

[7] Ottoman State Archive, ZB Zaptiye, 314-64-R-19-01-1325; (Providing information about Altarlioglu Ismail ibn Hasan and Arabistonlioglu Arab Ali oglu Ahmed who are studying in Naval school, 1907) İhtiyat efradından Tersane-i Amire Tamirat Fabrikası'nda mülazım-1 evvel oldukları haber alınan Altaroğlu İsmail Efendi bin Hasan ile Arabistanlıŏlu Arap Alioğlu Ahmed'in durumunun araştırılarak bilgi verilmesi.

[8] Vecihi Hürkuş 2000 Bir Tayyarecinin Anıları p. 142 Istanbul.

[9] Ottoman State Archive, BOA, 314-64-R-19-01-1325, (Regarding the two students from the Naval School) Zabtiye İhtiyat efradından Tersane-i Amire Tamirat Fabrikası'nda mülazım-1 evvel oldukları haber alınan Altaroğlu İsmail Efendi bin Hasan ile Arabistanlıoğlu Arap Alioğlu Ahmed'in durumunun araştırılarak bilgi verilmesi.

[10] Armaoğlu, Fahir (2004). 20. Yüzyıl Siyasi Tarihi (Cilt 1-2: 1914-1995), 1. Cilt, p. 334 Alkım Yayınevi, Ankara.

[11] Akgün, Seçil ve Uluğtekin, Murat, (1993), "Hilal-i Ahmer ve Trablusgarp Savaşı", OTAM, Ankara Üniversitesi Osmanlı Tarihi Araştırma ve Uygulama Merkezi, Dergisi Sayı: 3.

[12] Abdurrahim Rahmi Aydın 2001 Tayyareden Uçağa: Milli
Hava Sanayinin Kuruluşunda Türk Halkının Yaptığı Bağışlar pp. 53,54 .

[13] Osman Yalçın. 2010. Donated Aircrafts and Its Influences on Aerospace Industries in History of Turkish Aviation. Gazi University.

[14] Ottoman State Archive, HR. SYS. 2413/63 (Three airplanes were taken from Germany) Almanya'dan gelmekte olan üç tayyare. 1915.

[15] Ahmet Ali's younger brother died in the Great War at Gallipoli in 1915. See.

[16] Ajun Kurter, 2009 Türk Hava Kuvvetleri Tarihi, Cilt 5, Hava Kuvvetleri Komutanlığı, p. 299.

[17] The Nigerian Pioneer Friday, May 21st, 1915, Lagos.

[18] Ekmeleddin İhsanoğlu (2004). Osmanlı Askerlik Literatürü Tarihi. İslâm Tarih, Sanat ve Kültür Araştırma Merkezi. p. 741. İstanbul.

[19] Turkey. 1975. Kuruluş yıllarında Türk Askerî Havacıllı̆̆ belgeleri, 1909-1913. Etimesgut: Hv. Bas. ve Neş. Md. lügü. National government publication, p. 23. İstanbul.

[20] Ottoman State Archive, HR. SYS. 2251/38 British pilots captured by the Ottoman soldiers in Tribulus) Trablusgarp'da kıtaat ve mücahidini Osmaniye tarafindan esir edilen İngiliz pilotlarının Londra ve Malta'ya... 1917.

[21] Süreyya Ilmen 1947 Türk Tayyarecilik ve Balonculuk Tarihi, p 21, İstanbul.

[22] Ottoman State Archive, 2.130-11-1-0 B. T. D, (Retirement of particular Turkish commanders including Ahmet Ali Celikten 1948) Askeri memurlardan Ata Erbayav, Ahmet Çelikten, Zihni Göktan, Şükrü Sönmez ve Tüfekçi İ. Hakkı Değim'in yaş kaydından emekliye sevki. 199-20-116.07.1948.

[23] Deniz, Tuncay, and Werner Münzenmaier. 2008. Bildband, pictorial "Turkish Phantoms" the F-4 Phantom II of the Turk Hava Kuvvetleri.

[24] Dikduran, Salim. 2019. Türk hava kuvvetleri tarihinde astsubaylar. Istanbul: Türkiye Iş Bankası Kültür Yayınları.

[25] Harris, Henry Scott (2012). All Blood Runs Red: Life and Legends of Eugene Jacques Bullard: First Black American Military Aviator, USA.

[26] William I. Chivalette 2013 June 27 Corporal Eugene Jacques Bullard First Black American Fighter pilot Air \& Space Power Journal - Español Tercer Trimestre p. 6.

[27] American Aviation Publications. 1955. Who's who in world aviation. Washington, D.C.: American Aviation Publications. 